\title{
Update on human genetic susceptibility to COVID-19: susceptibility to virus and response
}

Vito Luigi Colona ${ }^{1}$, Vasilis Vasiliou², Jessica Watt ${ }^{3}$, Giuseppe Novelli ${ }^{1,4,5}$ and Juergen K. V. Reichardt $6^{*}$

\section{Introduction}

Over the past year and a half, SARS-CoV-2, the etiological agent of the COVID-19 pandemic, led to a total of almost 200 million cases, causing more than 4 million of deaths globally (Johns Hopkins University, CSSE) [1].

While we are facing rising daily hospitalizations (https://ourworldindata.org/covid-hospitalizations, accessed on July 31, 2021) [2], attributable to novel emerging variants of the virus [3, 4], we also observe a decrease in both hospitalizations due to severe forms of the disease and deaths in several parts of the world, thanks to the launch of massive vaccination campaigns [2]. To date, 4 billion vaccine doses have been administered [1]. Despite of the efforts of global organizations to face this health emergency, including the COVAX plan which aims to achieve the vaccination coverage in developing countries [5], we are still far from reaching the desired results and the end of this pandemic especially in emerging countries.

As we discussed in our recent review on "COVID19 one year into the pandemic: from genetics and genomics to therapy, vaccination, and policy" [6], vaccines represent one of the most valuable aid to halt the SARS-CoV-2 spread. The emergence of novel variants of concern (VOC) aroused concern among the scientific community, since they are associated with a rise

\footnotetext{
*Correspondence: juergen.reichardt@jcu.edu.au

${ }^{6}$ Australian Institute of Tropical Health and Medicine, James Cook

University, Smithfield, QLD 4878, Australia

Full list of author information is available at the end of the article
}

of viral transmissibility [7], and with a reduction in the therapeutic response to both monoclonal antibodies and antibody activity in vaccinated individuals [8]. Nevertheless, results arising from the analysis of vaccine coverage against the emerging Delta variant are promising [9].

It is known that the mRNA vaccines, both BNT162b2 (Pfizer/BioNTech) and mRNA-1273 (Moderna), can potentially be implemented to match the need of a response against SARS-CoV-2 mutations. For this reason, it is crucial to increase the genomic surveillance in the different departments of public health systems all over the world [10].

In the same publication [6], we arrive at the conclusion that not only the virus, but significantly also the synergic relationship with the host represents the core of the understanding of mechanisms underpinning the infectious cycle, transmission, resistance and susceptibility to SARS-CoV-2. In addition, we also expressed concern about effects that environmental pollution may exert on susceptibility to SARS-CoV-2 by diminishing immune responses. We are aware that increased knowledge of this aspects is fundamental to unveil the clinical course and a more targeted therapeutical approach for patients affected by COVID-19.

In this editorial, we focus on genetic and genomics susceptibility factors to COVID-19, and we aim to summarize the current knowledge in the literature providing an updated, easy to consult and constantly revised tool, through an update of Table 2 from our recent review [6]. give appropriate credit to the original author(s) and the source, provide a link to the Creative Commons licence, and indicate if changes were made. The images or other third party material in this article are included in the article's Creative Commons licence, unless indicated otherwise in a credit line to the material. If material is not included in the article's Creative Commons licence and your intended use is not permitted by statutory regulation or exceeds the permitted use, you will need to obtain permission directly from the copyright holder. To view a copy of this licence, visit http://creativecommons.org/licenses/by/4.0/. The Creative Commons Public Domain Dedication waiver (http://creativecommons.org/publicdomain/zero/1.0/) applies to the data made available in this article, unless otherwise stated in a credit line to the data. 


\section{Discussion}

Going beyond the one-year landmark into the pandemic caused by SARS-CoV-2, we perceive that an in-depth analysis of human genetic susceptibility to the severity of the disease is becoming increasingly crucial.

Table 1 summarizes ultra-rare, rare and common human variants, haplotypes, and susceptibility gene polymorphisms detected in several studies, through various approaches [11-17].

Genome-wide association studies (GWAS) led to the identification of susceptibility alleles in several genes, which are linked to severe and/or life-threatening phenotypes. So far, some of the risk values turned out to be too low ( $\mathrm{OR}<2$; odds ratio) to be considered as predictive genomic markers. Nevertheless, it cannot be excluded that the additive effect of these alleles could contribute to a polygenic risk score analysis [18]. On the other hand, high penetrance alleles of genes encoding for proteins involved in crucial homeostasis pathways might be useful for patient stratification and may potentially impact the prognostic field and the pharmacological treatment [19, 20]. However, we have to consider that in a polygenic and multifactorial disease such as COVID-19, several genetic and epigenetic factors are able to regulate phenotypic expression, complicating a possible genotype-phenotype correlation analysis. Pathway analyses are to be considered. In fact, genes encoding for proteins involved in molecular mechanisms of innate immunity and humoral response were among the first candidate genes to be analyzed [19-21].

Innate immunity represents the first immediate, nonspecific and autonomous defense line of our immune system and plays a fundamental role against pathogens, including SARS-CoV-2 [22]. Innate immune system deficits can be the basis of heterogeneity in clinical phenotypes and of the outcome of patients affected by COVID-19. This evidence is supported not only by recent discoveries in the genetic field [11, 20,23], but also by the description of novel mechanisms for the interaction network between viral proteins and host factors [24]. As mentioned in our recent review [6], identifying the functional role of rare variants will allow us to unveil the pathogenetic mechanisms, but also to improve the efficiency of predictive tests for the benefit of a better therapeutical approach in the context of a personalized medicine. Environmental factors also need to be considered.

Zhang et al. [20] and Bastard et al. [21] described the presence of alleles underpinning altered type $1 \mathrm{~b}$ Interferon (IFN-1b) response in critical patients, and proved that anti-interferon antibodies in the serum of affected individuals in critical conditions are capable of halting the IFN activity. Furthermore, the presence of these antibodies in patients with severe phenotype that required hospitalization to intensive care units (ICU) was successfully proved, establishing a correlation with an high mortality rate [25]. In a further study [26] a significant difference in the amount of inflammatory cytokines emerged in a comparison between cells collected through bronchoalveolar lavage (BAL) in SARS-CoV-2 positive patients and cells collected from patients afflicted by pneumonia of bacterial or viral origin. This shows us how the virus-triggered pyroptosis induces a profound alteration of the immune response, which is also and above all influenced by the host genetic background. A work [19] coordinated by the international consortium CHGE (Covid Human Genetic Effort, https://www.covidhge. com/about) shows that 3\% of COVID-19 patients who harbor Loss-of-Function (LoF) variants in loci of genes involved in the response to viral infection pathway has a severe/life-threatening phenotype, estimating an OR around 9 in an autosomal dominant model, and between 50 and 100 in an autosomal recessive model (Table 1).

In addition, further evidence shed a light on the ability of SARS-CoV-2 to adopt several strategies to antagonize the IFNs system, with a subsequent reduction in the type I IFN response [27-29]. It is known, indeed, that the elaborate IFNs system exerts its function in various aspects of the immune response, both innate and adaptive, also filling a role in the immunosurveillance [30]. It follows that congenital defects of this network, together with several comorbidities, are responsible for an inauspicious clinical course and can be counted among severity and susceptibility alleles with an higher-risk estimation impact (Table 1).

In an interesting association study from the 2020 performed in the United Kingdom, based on a cohort of 2,244 severely affected patients, Pairo-Castineira et al. [11] identified novel potential susceptibility alleles listed below and shown in Table 1: rs74956615 (3'UTR variant of TYK2; $\mathrm{OR}=1.6 ; \mathrm{AF}=0.03$ ); rs 143334143 (intronic variant of CCHCR1; OR = 1.9; AF=0.09); rs9380142 (3'UTR variant of $\mathrm{HLA}-\mathrm{G} ; \mathrm{OR}=13 ; \mathrm{AF}=0.29) ; \quad \mathrm{rs} 2109069$ (intronic variant of $D P P 9 ; \quad \mathrm{OR}=1.4 ; \quad \mathrm{AF}=0.33$ ); rs10735079 (intronic variant of $O A S 1 / 3 ; \mathrm{OR}=1.3$; $\mathrm{AF}=0.64$ ); rs2236757 (intronic variant of IFNAR2; $\mathrm{OR}=1.3 ; \mathrm{AF}=0.71$ ); rs3131294 (intronic variant of NOTCH4; $\mathrm{OR}=1.5 ; \mathrm{AF}=0.90$ ); rs73064425 (intronic variant of $L Z T F L 1 ; \mathrm{OR}=2.1 ; \mathrm{AF}=0.08$ ). In this study, a reduced expression of IFNAR2 and a high expression of $T Y K 2$, both involved in the IFN type I immune response pathway, have been associated with severe forms of COVID-19 [11]. Particularly, the putative role of TYK2, a tyrosine kinase belonging to the Janus proteins family (JAKs), in the disease severity progression allowed some researchers to speculate on a possible use of specific class 
Table 1 Genetic risk factors for severe COVID-19

\begin{tabular}{|c|c|c|c|}
\hline SARS-CoV-2 susceptibility gene variant or haplotype & $\begin{array}{l}\text { Risk } \\
\text { estimated } \\
\text { [OR] }\end{array}$ & Frequency [MAF] & References \\
\hline $\begin{array}{l}\text { TLR3, UNC93B1, TICAM1, TBK1, IRF3, IRF7, IFNAR1, IFNAR2 (autoso- } \\
\text { mal-dominant model) }\end{array}$ & 9 & $<0.001$ & Zhang et al. [20] \\
\hline IRF7, IFNAR1 (autosomal-recessive model) & $>50$ & $<0.001$ & Zhang et al. [20] \\
\hline rs769208985—missense variant of FURIN & N.A & $<0.001$ & Latini et al. [71] \\
\hline rs150892504-missense variant of ERAP2 & N.A & 0.002 & Hu et al. [60] \\
\hline rs138763430—-missense variant of BRF2 & N.A & 0.002 & Hu et al. [60] \\
\hline rs147149459-missense variant of ALOXE3 & N.A & 0.002 & Hu et al. [60] \\
\hline rs117665206-missense variant of TMEM181 & N.A & 0.006 & Hu et al. [60] \\
\hline rs114363287-missense variant of TMPRSS2 & N.A & 0.006 & Latini et al. [71] \\
\hline rs61756766-missense variant of TNFRSF13C & 12.3 & 0.008 & Russo et al. [61] \\
\hline rs7626962 — missense variant of SCN5A & 8.7 & 0.008 & SeyedAlinaghi et al. [62] \\
\hline rs1805128-missense variant of KCNE1 & 9.0 & 0.009 & SeyedAlinaghi et al. [62] \\
\hline HLA-DRB*27:07 & N.A & 0.02 & Novelli et al. [51] \\
\hline rs72711165 - intronic variant of TMEM65 & 1.2 & 0.02 & COVID-19 H.G.I. [66] \\
\hline rs115492982 -intronic variant of MRPS21 & 2.5 & 0.02 & Dite et al. [63] \\
\hline rs74956615 - 3'UTR variant of TYK2 & 1.6 & 0.03 & Pairo-Castineira et al. [11] \\
\hline rs2034831 —intronic variant of ITGA4 & 1.2 & 0.05 & Dite et al. [63] \\
\hline rs76374459-intronic variant of LZTFL1 & 1.2 & 0.05 & Dite et al. [63] \\
\hline rs35652899_intronic variant of LZTFL 1 & 1.2 & 0.05 & Dite et al. [63] \\
\hline rs10490770_intronic variant of LZTFL1 & 2.0 & 0.06 & COVID-19 H.G.I. [66] \\
\hline rs333-CCR5- $\triangle 32$ & 0.7 & 0.07 & Cuesta-Llavona et al. [76] \\
\hline rs73064425 - intronic variant of LZTFL 1 & 2.1 & 0.08 & Pairo-Castineira et al. [1 1 ], Ellinghaus et al. [23] \\
\hline rs11385942 - intronic variant of LZTFL1 & 1.8 & 0.07 & Ellinghaus et al. [23] \\
\hline rs1886814-intronic variant of FOXP4 & 1.3 & 0.07 & COVID-19 H.G.I. [66] \\
\hline rs76488148-intronic variant of GYG1 & 1.3 & 0.07 & Dite et al. [63] \\
\hline rs2271616-5'UTR variant of SLC6A20 & 1.1 & 0.08 & COVID-19 H.G.I. [66] \\
\hline HLA-DQB1*06:02 & N.A & 0.08 & Novelli et al. [51] \\
\hline rs143334143-intronic variant of CCHCR1 & 1.9 & 0.09 & Pairo-Castineira et al. [11] \\
\hline HLA-DRB1*15:01 & N.A & 0.10 & Novelli et al. [51] \\
\hline rs12252:G allele of IFITM3 & 2.2 & 0.13 & Alghamdi et al. [52] \\
\hline rs4801778 - intronic variant of PLEKHA4 & 1.0 & 0.16 & COVID-19 H.G.I. [66] \\
\hline rs6598045—5'UTR variant of IFITM3 & N.A & 0.19 & Kim et al. [53] \\
\hline rs429358 - missense variant of APOE & $2.3-2.4$ & 0.20 & Kuo et al. [65] \\
\hline rs12610495-intronic variant of DPP9 & N.A & 0.25 & Moon et al. [41] \\
\hline rs12329760_intronic variant of TMPRSS2/MX1 & 0.9 & 0.25 & Andolfo et al. [72] \\
\hline rs2298661_missense variant of TMPRSS2/MX1 & 0.9 & 0.25 & Andolfo et al. [72] \\
\hline rs3787946 —intronic variant of TMPRSS2/MX1 & 0.9 & 0.28 & Andolfo et al. [72] \\
\hline rs9983330 - intronic variant of TMPRSS2/MX1 & 0.9 & 0.28 & Andolfo et al. [72] \\
\hline rs9380142-3'UTR variant of HLA-G & 13 & 0.29 & Pairo-Castineira et al. [11] \\
\hline rs2109069—intronic variant of DPP9 & 1.4 & 0.33 & Pairo-Castineira et al. [11], COVID-19 H.G.I. [66] \\
\hline rs9985159_intronic variant of TMPRSS2/MX1 & 0.9 & 0.33 & Andolfo et al. [72] \\
\hline Rs75603675-missense variant of TMPRSS2 & N.A & 0.36 & Latini et al. [71] \\
\hline rs1405655-intronic variant of NR1H2 & 1.1 & 0.37 & COVID-19 H.G.I. [66] \\
\hline rs12329760—missense variant of TMPRSS2 & 0.9 & 0.39 & Hou et al. [73] \\
\hline rs657152-intronic variant of $A B O$ & 1.3 & 0.41 & Ellinghaus et al. [23] \\
\hline rs677800_-intronic variant of $A B O$ & N.A & 0.55 & Moon et al. [41] \\
\hline rs6020298_-intronic variant of TMEM189-UBE2V1 & 1.2 & 0.58 & Wang et al. [74] \\
\hline rs10735079_-intronic variant of OAS1/3 & 1.3 & 0.64 & Pairo-Castineira et al. [11] \\
\hline
\end{tabular}


Table 1 (continued)

\begin{tabular}{|c|c|c|c|}
\hline SARS-CoV-2 susceptibility gene variant or haplotype & $\begin{array}{l}\text { Risk } \\
\text { estimated } \\
{[O R]}\end{array}$ & Frequency [MAF] & References \\
\hline rs8065800-intronic variant of MAPT & 1.7 & 0.65 & COVID-19 H.G.I. [66] \\
\hline rs10774671 —intronic, splicing variant of OAS1 & 1.1 & 0.67 & COVID-19 H.G.I. [66] \\
\hline rs13050728 -intronic variant of IFNAR2 & 0.9 & 0.69 & COVID-19 H.G.I. [66] \\
\hline rs2236757-intronic variant of IFNAR2 & 1.3 & 0.71 & Pairo-Castineira et al. [11] \\
\hline rs3131294-intronic variant of NOTCH4 & 1.5 & 0.90 & Pairo-Castineira et al. [11] \\
\hline HLA-A*11 & N.A & N.A & Fricke-Galindo et al. [54] \\
\hline HLA-A*11:01:01:01 & 2.3 & N.A & Khor et al. [56] \\
\hline HLA-A*25:01 & N.A & N.A & Fricke-Galindo et al. [54] \\
\hline HLA-B*46:01 & 2.1 & N.A & Lin et al. [53], Fricke-Galindo et al. [54] \\
\hline HLA-B*51:01 & N.A & N.A & Fricke-Galindo et al. [54] \\
\hline HLA B*54:01 & 5.4 & N.A & Lin et al. [55] \\
\hline HLA-C*01 & N.A & N.A & Fricke-Galindo et al. [54] \\
\hline HLA-C*01:02 & N.A & N.A & Fricke-Galindo et al. [54] \\
\hline HLA-C*05 & N.A & N.A & Fricke-Galindo et al. [54] \\
\hline HLA-C*12:02:02:01-HLA*52:01:02:02 & 2.3 & N.A & Khor et al. [56] \\
\hline HLA-C*14:02 & N.A & N.A & Fricke-Galindo et al. [54] \\
\hline HLA-C*17 & N.A & N.A & Bonaccorsi et al. [57] \\
\hline HLA-DQB1*04 & N.A & N.A & Fricke-Galindo et al. [54] \\
\hline HLA-DQB1*08 & N.A & N.A & Fricke-Galindo et al. [54] \\
\hline HLA-E*0101/0103 & $2.1-2.7$ & N.A & Vietzen et al. [58] \\
\hline$K L R C 2^{\text {del }}$ & $2.6-7.1$ & N.A & Vietzen et al. [58] \\
\hline ACE1 I/D genotype & 2.5 & N.A & Verma et al. [69] \\
\hline C9orf72 with HREs > 10 units & 2.4 & N.A & Zanella et al. [64] \\
\hline c.2129_2132del, p.Gln710Argfs*18_frameshift variant of TLR7 & N.A & N.A & van der Made et al. [42] \\
\hline c.2383G > T, p.Val795Phe-missense variant of $T L R 7$ & N.A & N.A & van der Made et al. [42] \\
\hline c.644A > G, p.Asn215Ser — missense variant of TLR7 & N.A & N.A & Solanich et al. [43] \\
\hline c.2797 T > C, p.Trp933Arg — missense variant of TLR7 & N.A & N.A & Solanich et al. [43] \\
\hline c.901 T > C, p.Ser301Pro—missense variant of TLR7 & N.A & N.A & Fallerini et al. [44] \\
\hline c.3094G > A, p.Ala1032Thr — missense variant of TLR7 & N.A & N.A & Fallerini et al. [44] \\
\hline c.2759G > A, p.Arg920Lys—-missense variant of TLR7 & N.A & N.A & Fallerini et al. [44] \\
\hline c.863C > T, p.Ala288Val—missense variant of TLR7 & N.A & N.A & Fallerini et al. [44] \\
\hline c.1342C > T, p.Ala448Val—missense variant of TLR7 & N.A & N.A & Fallerini et al. [44] \\
\hline c.655G > A, p.Val219lle — missense variant of TLR7 & N.A & N.A & Fallerini et al. [44] \\
\hline rs140312271_-missense variant of ACE2 & N.A & N.A & Novelli et al. [75] \\
\hline
\end{tabular}

MAF Major Allele Frequency; N.A. Not Applicable; OR Odds Ratio

of JAK inhibitor compounds. This class enlists the monoclonal antibody baricitinib. Several studies reported the efficiency of the compound whether in association or not with a steroid therapy, and/or with other compounds (e.g., Remdesivir) [31-36].

DPP9 is located on chromosome 19p13.3 and encodes for a serine protease, the dipeptidyl peptidase 9 , and is involved in several stages of the inflammatory response [37-39]. Variants affecting this locus are known to be associated with idiopathic pulmonary fibrosis [40]. From our rapid literature review, a second intronic variant of
DDP9 gene has been accounted among the risk allele for COVID-19 (rs12610495, Table 1) [41]. The latter is another example of how a predisposition to an altered pathophysiology, due to a specific genetic background of the host, might lead the patient through a poor prognosis.

It is noteworthy the discovery of two rare and deleterious germinal variants of the TLR7 gene in two couples of young male siblings with no reported comorbidities and displaying a severe COVID-19 phenotype: the frameshift variant with maternal segregation c.2129_2132del, p.Gln710Argfs"18 and the missense variant c.2383G > T, 
p.Val795Phe (Table 1) [42]. The alteration of the response to type I and type II IFN subsequent to imiquimod administration, a TLR7 receptor agonist, confirmed the importance of the maintenance of TLR pathway in COVID-19 pathogenesis [42, 43]. These results found confirmation in a recent independent cohort study performed in Italy, which highlighted the presence of deleterious variants of TLR7 in $2.1 \%$ of severely affected males in comparison with asymptomatic individuals [44]. The specific missense variants are reported in the third section of Table 1. It is known that complete deficit of TLR7 is extremely rare because members of TLRs family (TLR3, TLR7, TLR8 e TLR9) carry out specific and nonredundant activities for the host survival $[45,46]$. Variants of the TLR7 gene are associated with the immune response against single-stranded RNA virus and to the onset of autoimmune disease such as systemic lupus erythematosus (SLE) [47].

Several scientific contributions focused on the potential relevance of HLA complex polymorphisms for SARSCoV-2 susceptibility (Table 1 ) [23, 48-58] and for the disease severity extent [59].

The estimate of predictive models deserves a separate discussion. Due to the availability of international biobanks, it has been possible to identify and confirm novel susceptibility loci for COVID-19 [60-66]. Thirteen novel susceptibility loci have been linked to several aspects of SARS-CoV-2 infection as a result of a recent meta-analysis performed by COVID-19 Host Genetics Initiative (COVID-19 H.G.I.) [67]. However, many of those overlap previously reported associations [11, 23, 41], among which the $A B O$ loci variants (Table 1$)[23,41]$ and the 5'UTR variant of SLC6A2O (rs2271616; OR=1.1; $\mathrm{AF}=0.08$. Table 1 ), which seem to have a major role in infection susceptibility and in the negative progression of the disease [67].

It has been proved that expression levels of genes encoding for proteins involved in the viral uptake (e.g., ACE2, TMPRSS2, FURIN) change with age, which depicts a biological rationale for the broad phenotypic spectrum of COVID-19 [68]. Age and sex, indeed, represent non-genetic factors that primarily influence disease severity [69], but not exclusively. Verma et al. [70] reported a correlation between ACE I/D $(\mathrm{OR}=2.5$. Table 1) polymorphism and a cluster of patients affected by diabetes mellitus and high blood pressure.

Blume et al. [71] identified a new isoform of ACE2, mainly expressed in rhino-oropharynx mucosa. This is downregulated in response to IFN, but not from SARS$\mathrm{CoV}-2$. For this reason, we think that characterization of $A C E 2$ promoter functional elements and its regulatory factors represents a fundamental support for the understanding of viral molecular mechanisms. Several studies showed that the presence of rare or novel variants of those genes might be responsible for diversification of the response (Table 1) [72-76].

Last but not least, nowadays, the role of co-receptor 5 (CCR5) deletion 32 in coronavirus susceptibility is still controversial [77-80].

\section{Conclusions}

The current COVID-19 pandemic has had, and will continue to have, a significant impact on humanity. We are aware that not only will society change, but also the way of approaching science. As scientists, we can only be proud of how so many highly skilled research laboratories have been able to put aside their differences to cooperate and achieve extraordinary results [6], opening the way to translational research [81] and personalized medicine [82].

Furthermore, it is clear that precision medicine has the potential to reduce side effects and to reduce hospitalization costs and duration [83]. Studying new therapeutic approaches [84-88], unveiling new molecular mechanisms [88-90], understanding the implications of possible susceptibility alleles in the exposed population [91, 92], will allow us to broaden our contribution to the fight against the current coronavirus outbreak and against upcoming agents which, inevitably, will show up in the near future [93]. With this goal, we make the commitment to constantly update the tool provided within this paper with new data, in order to have an even more precise, in-depth and proactive overview.

\section{Abbreviations}

ACE2: Adenosine-Converting Enzyme; BAL: Broncoalveolar Lavage; CHGE: Covid Human Genetic Effort; COVAX: COVID-19 Vaccines Global Access; COVID-19: Coronavirus Disease 2019; COVID-19 H.G.I: COVID-19 Host Genetics Initiative; CSSE: Center for Systems Science and Engineering; DPP9: Dipeptidyl Peptidase 9; GWAS: Genome-Wide Association Study; ICU: Intensive Care Unit; IFNAR: Interferon-a/b receptor; IFN: Interferon; HLA: Human Leucocyte Antigen; HREs: Hexanucleotide Repeat Expansions; LoF: Loss-of-Function; OR: Odd Ratio; ORF: Open Reading Frame; SARS-CoV-2: Severe Acute Respiratory Syndrome Coronavirus 2; SLE: Systemic Lupus Erythematous; TLR: Toll-like Receptor; TMPRSS2: Transmembrane Serine Protease 2; VOC: Variant Of Concern.

\section{Acknowledgement}

Supported by Regione Lazio through Laziolnnova Progetto Gruppo di Ricerca n A0375-2020-36663 GecoBiomark to GN.

\section{Authors' contributions}

V.L.C. wrote the manuscript, performed the systematic review, conceived and edited Table 1. G.N. and J.K.V.R. conceived the paper, cowrote and revised the manuscript. V.V. and J.W. edited the manuscript. All authors read and approved the final manuscript.

Availability of data and materials

Data sharing is not applicable to this article as no datasets were generated or analyzed during the current study. 


\section{Declarations}

Ethics approval and consent to participate

Not applicable.

\section{Consent for publication}

Not applicable.

\section{Competing interests}

The authors declare no competing interests.

\section{Author details}

${ }^{1}$ Department of Biomedicine and Prevention, "Tor Vergata" University of Rome, 00133 Rome, Italy. ${ }^{2}$ Department of Environmental Health Sciences, School of Public Health, Yale University, New Haven, USA. ${ }^{3}$ College of Public Health, Medical and Veterinary Sciences, James Cook University, Smithfield, QLD, Australia. ${ }^{4}$ IRCCS Neuromed, Pozzilli, IS, Italy. ${ }^{5}$ Department of Pharmacology, School of Medicine, University of Nevada, Reno, NV 89557, USA. ${ }^{6}$ Australian Institute of Tropical Health and Medicine, James Cook University, Smithfield, QLD 4878, Australia.

Published online: 25 August 2021

\section{References}

1. Dong E, Du H, Gardner L. An interactive web-based dashboard to track COVID-19 in real time. Lancet Infect Dis. 2020;20(5):533-534. Epub 2020 Feb 19. Erratum in: Lancet Infect Dis. 2020 Sep;20(9):e215. https://doi.org/ 10.1016/S1473-3099(20)30120-1.

2. Ritchie H, Ortiz-Ospina E, Beltekian D, Mathieu E, Hasell J, Macdonald B, et al. Coronavirus Pandemic (COVID-19). Published online at OurWorldInData.org (2020). Retrieved from: https://ourworldindata.org/coronavirus.

3. Sanyaolu A, Okorie C, Marinkovic A, Haider N, Abbasi AF, Jaferi U, et al. The emerging SARS-CoV-2 variants of concern. Ther Adv Infect Dis. 2021;18(8):20499361211024372. https://doi.org/10.1177/2049936121 1024372.

4. Novelli G, Colona VL, Pandolfi PP. A focus on the spread of the delta variant of SARS-CoV-2 in India. Indian J Med Res. 2021. Epub ahead of print. https://doi.org/10.4103/ijmr.ijmr_1353_21.

5. Bolcato M, Rodriguez D, Feola A, Di Mizio G, Bonsignore A, Ciliberti R, Tettamanti C, Trabucco Aurilio M, Aprile A. COVID-19 Pandemic and equal access to vaccines. Vaccines (Basel). 2021;9(6):538. https://doi.org/10. 3390/vaccines 9060538.

6. Novelli G, Biancolella M, Mehrian-Shai R, Colona VL, Brito AF, Grubaugh $N D$, et al. COVID-19 one year into the pandemic: from genetics and genomics to therapy, vaccination, and policy. Hum Genom. 2021;15(1):27. https://doi.org/10.1186/s40246-021-00326-3.

7. Singh J, Samal J, Kumar V, Sharma J, Agrawal U, Ehtesham NZ, et al. Structure-Function analyses of new SARS-CoV-2 variants B.1.1.7, B.1.351 and B.1.1.28.1: clinical, diagnostic, therapeutic and public health implications. Viruses. 2021;13(3):439. https://doi.org/10.3390/v13030439.

8. Weisblum Y, Schmidt F, Zhang F, DaSilva J, Poston D, Lorenzi JC, et al. Escape from neutralizing antibodies by SARS-CoV-2 spike protein variants. Elife. 2020;28(9): e61312. https://doi.org/10.7554/eLife.61312.

9. Lopez Bernal J, Andrews N, Gower C, Gallagher E, Simmons R, Thelwall $\mathrm{S}$, et al. Effectiveness of Covid-19 vaccines against the B.1.617.2 (Delta) Variant. N Engl J Med. 2021. https://doi.org/10.1056/NEJMoa2108891.

10. Cyranoski D. Alarming COVID variants show vital role of genomic surveillance. Nature. 2021;589(7842):337-8. https://doi.org/10.1038/ d41586-021-00065-4.

11. Pairo-Castineira E, Clohisey S, Klaric L, Bretherick AD, Rawlik K, Pasko D, et al. Genetic mechanisms of critical illness in COVID-19. Nature. 2021;591(7848):92-98. Epub 2020 Dec 11. https://doi.org/10.1038/ s41586-020-03065-y.

12. Novelli G, Biancolella M, Mehrian-Shai R, Erickson C, Godri Pollitt KJ, Vasiliou $V$, et al. COVID-19 update: the first 6 months of the pandemic. Hum Genom. 2020;14(1):48. https://doi.org/10.1186/s40246-020-00298-w.
13. Curtis D. Variants in ACE2 and TMPRSS2 genes are not major determinants of COVID-19 severity in UK Biobank Subjects. Hum Hered. 2020;85(2):66-68. Epub 2021 Mar 22. https://doi.org/10.1159/000515200.

14. Elhabyan A, Elyaacoub S, Sanad E, Abukhadra A, Elhabyan A, Dinu V. The role of host genetics in susceptibility to severe viral infections in humans and insights into host genetics of severe COVID-19: A systematic review. Virus Res. 2020;289:198163. Epub 2020 Sep 9. https://doi.org/10.1016/j. virusres.2020.198163.

15. Oh JH, Tannenbaum A, Deasy JO. Identification of biological correlates associated with respiratory failure in COVID-19. BMC Med Genom. 2020;13(1):186. https://doi.org/10.1186/s12920-020-00839-1.

16. Yuan J, Fan D, Xue Z, Qu J, Su J. Co-expression of mitochondrial genes and ACE2 in cornea involved in COVID-19. Investig Ophthalmol Vis Sci. 2020;61(12):13. https://doi.org/10.1167/iovs.61.12.13.

17. Smatti MK, Al-Sarraj YA, Albagha O, Yassine HM. Host genetic variants potentially associated with SARS-CoV-2: a multi-population analysis. Front Genet. 2020;2(11): 578523. https://doi.org/10.3389/fgene.2020.578523.

18. Duncan L, Shen H, Gelaye B, Meijsen J, Ressler K, Feldman M, et al. Analysis of polygenic risk score usage and performance in diverse human populations. Nat Commun. 2019;10(1):3328. https://doi.org/10.1038/ s41467-019-11112-0.

19. Zhang Q, Bastard P, Bolze A, Jouanguy E, Zhang SY, Cobat A, et al. Lifethreatening COVID-19: defective interferons unleash excessive inflammation. Med (N Y). 2020;1(1):14-20. https://doi.org/10.1016/j.medj.2020.12. 001.

20. Zhang Q, Bastard P, Liu Z, Le Pen J, Moncada-Velez M, Chen J, et al. Inborn errors of type I IFN immunity in patients with life-threatening COVID-19. Science. 2020;370(6515):eabd4570. Epub 2020 Sep 24. https://doi.org/10. 1126/science.abd4570.

21. Bastard P, Rosen LB, Zhang Q, Michailidis E, Hoffmann HH, Zhang Y, et al. Autoantibodies against type I IFNs in patients with life-threatening COVID-19. Science. 2020;370(6515):eabd4585. Epub 2020 Sep 24. https:// doi.org/10.1126/science.abd4585.

22. Schultze JL, Aschenbrenner AC. COVID-19 and the human innate immune system. Cell. 2021;184(7):1671-1692. Epub 2021 Feb 16. https:// doi.org/10.1016/j.cell.2021.02.029.

23. Ellinghaus D, Degenhardt F, Bujanda L, Buti M, Albillos A, Invernizzi P, et al. Genomewide association study of severe Covid-19 with respiratory failure. N Engl J Med. 2020;383(16):1522-1534. Epub 2020 Jun 17. https:// doi.org/10.1056/NEJMoa2020283.

24. Gordon DE, Jang GM, Bouhaddou M, Xu J, Obernier K, White KM, et al. A SARS-CoV-2 protein interaction map reveals targets for drug repurposing. Nature. 2020;583(7816):459-468. Epub 2020 Apr 30. https://doi.org/10. 1038/s41586-020-2286-9.

25. Koning R, Bastard P, Casanova JL, Brouwer MC, van de Beek D; with the Amsterdam U.M.C. COVID-19 Biobank Investigators. Autoantibodies against type I interferons are associated with multi-organ failure in COVID-19 patients. Intensive Care Med. 2021;47(6):704-706. Epub 2021 Apr 9. https://doi.org/10.1007/s00134-021-06392-4.

26. Liao M, Liu Y, Yuan J, Wen Y, Xu G, Zhao J, et al. Single-cell landscape of bronchoalveolar immune cells in patients with COVID-19. Nat Med. 2020;26(6):842-844. Epub 2020 May 12. https://doi.org/10.1038/ s41591-020-0901-9.

27. Acharya D, Liu G, Gack MU. Dysregulation of type I interferon responses in COVID-19. Nat Rev Immunol. 2020;20(7):397-398. Epub 2020 May 26. https://doi.org/10.1038/s41577-020-0346-x.

28. Blanco-Melo D, Nilsson-Payant BE, Liu WC, Uhl S, Hoagland D, Møller R, et al. Imbalanced host response to SARS-CoV-2 drives development of COVID-19. Cell. 2020;181(5):1036-1045.e9. Epub 2020 May 15. https://doi. org/10.1016/j.cell.2020.04.026.

29. Sa Ribero M, Jouvenet N, Dreux M, Nisole S. Interplay between SARSCoV-2 and the type I interferon response. PLoS Pathog. 2020;16(7): e1008737. https://doi.org/10.1371/journal.ppat.1008737.

30. Takaoka A, Hayakawa S, Yanai H, Stoiber D, Negishi H, Kikuchi H, et al. Integration of interferon-alpha/beta signalling to p53 responses in tumour suppression and antiviral defence. Nature. 2003;424(6948):516-23. https://doi.org/10.1038/nature01850.

31. Pérez-Alba E, Nuzzolo-Shihadeh L, Aguirre-García GM, Espinosa-Mora J, Lecona-Garcia JD, Flores-Pérez RO, et al. Baricitinib plus dexamethasone compared to dexamethasone for the treatment of severe COVID19 pneumonia: a retrospective analysis. J Microbiol Immunol Infect. 
2021:S1684-1182(21)00133-X. Epub ahead of print. https://doi.org/10. 1016/j.jmii.2021.05.009.

32. Abizanda P, Calbo Mayo JM, Mas Romero M, Cortés Zamora EB, Tabernero Sahuquillo MT, Romero Rizos L, et al. Baricitinib reduces 30-day mortality in older adults with moderate-to-severe COVID-19 pneumonia. J Am Geriatr Soc. 2021. Epub ahead of print. https://doi.org/10.1111/jgs. 17357.

33. Kalil AC, Patterson TF, Mehta AK, Tomashek KM, Wolfe CR, Ghazaryan V, et al. Baricitinib plus Remdesivir for hospitalized adults with Covid-19. N Engl J Med. 2021;384(9):795-807. Epub 2020 Dec 11. https://doi.org/10. 1056/NEJMoa2031994.

34. Rizk JG, Forthal DN, Kalantar-Zadeh K, Mehra MR, Lavie CJ, Rizk Y, et al. Expanded access programs, compassionate drug use, and emergency use authorizations during the COVID-19 pandemic. Drug Discov Today. 2021;26(2):593-603. Epub 2020 Nov 27. https://doi.org/10.1016/j.drudis. 2020.11.025.

35. Takahashi T, Luzum JA, Nicol MR, Jacobson PA. Pharmacogenomics of COVID-19 therapies. NPJ Genom Med. 2020;18(5):35. https://doi.org/10. 1038/s41525-020-00143-y.

36. Gilzad-Kohan H, Jamali F. Anti-inflammatory properties of drugs used to control COVID-19 and their effects on the renin-angiotensin system and angiotensin-converting enzyme-2. J Pharm Pharm Sci. 2020;23:259-277. https://doi.org/10.18433/jpps31346.

37. Zhang H, Maqsudi S, Rainczuk A, Duffield N, Lawrence J, Keane FM, et al. Identification of novel dipeptidyl peptidase 9 substrates by two-dimensional differential in-gel electrophoresis. FEBS J. 2015;282(19):3737-57. Epub 2015 Aug 3. https://doi.org/10.1111/febs.13371.

38. Geiss-Friedlander R, Parmentier N, Möller U, Urlaub H, Van den Eynde BJ, Melchior F. The cytoplasmic peptidase DPP9 is rate-limiting for degradation of proline-containing peptides. J Biol Chem. 2009;284(40):27211-9. Epub 2009 Aug 10. https://doi.org/10.1074/jbc.M109.041871.

39. Griswold AR, Ball DP, Bhattacharjee A, Chui AJ, Rao SD, Taabazuing CY, Bachovchin DA. DPP9's Enzymatic activity and not its binding to CARD8 inhibits inflammasome activation. ACS Chem Biol. 2019;14(11):24242429. Epub 2019 Sep 20. https://doi.org/10.1021/acschembio.9b00462.

40. Fingerlin TE, Murphy E, Zhang W, Peljto AL, Brown KK, Steele MP, et al. Genome-wide association study identifies multiple susceptibility loci for pulmonary fibrosis. Nat Genet. 2013;45(6):613-20. Epub 2013 Apr 14. Erratum in: Nat Genet. 2013 Nov;45(11):1409. https://doi.org/10.1038/ng. 2609.

41. Moon CY, Schilder BM, Raj T, Huang KL. Phenome-wide and expression quantitative trait locus associations of coronavirus disease 2019 genetic risk loci. iScience. 2021;24(6):102550. Epub 2021 May 18. https://doi.org/ 10.1016/j.isci.2021.102550

42. van der Made Cl, Simons A, Schuurs-Hoeijmakers J, van den Heuvel G, Mantere T, Kersten $\mathrm{S}$, et al. Presence of genetic variants among young men with severe COVID-19. JAMA. 2020;324(7):663-73. https://doi.org/10. 1001/jama.2020.13719.

43. Solanich X, Vargas-Parra G, Caspar I, van del Made, Simons A, SchuursHoeijmakers J, et al. Genetic screening for TLR7 variants in young and previously healthy men with severe COVID-19. Front Immunol. 2021;12:2965. https://doi.org/10.3389/fimmu.2021.719115.

44. Fallerini C, Daga S, Mantovani S, Benetti E, Picchiotti N, Francisci D, et al. Association of Toll-like receptor 7 variants with life-threatening COVID19 disease in males: findings from a nested case-control study. Elife. 2021;2(10): e67569. https://doi.org/10.7554/eLife.67569.

45. Casanova JL, Abel L, Quintana-Murci L. Human TLRs and IL-1Rs in host defense: natural insights from evolutionary, epidemiological, and clinical genetics. Annu Rev Immunol. 2011;29:447-91. https://doi.org/10.1146/ annurev-immunol-030409-101335.

46. Plenge RM. Molecular underpinnings of severe coronavirus disease 2019. JAMA. 2020;324(7):638-9. https://doi.org/10.1001/jama.2020.14015.

47. Shen N, Fu Q, Deng Y, Qian X, Zhao J, Kaufman KM, et al. Sex-specific association of X-linked Toll-like receptor 7 (TLR7) with male systemic lupus erythematosus. Proc Natl Acad Sci USA. 2010;107(36):15838-43. Epub 2010 Aug 23. https://doi.org/10.1073/pnas.1001337107.

48. Barquera R, Collen E, Di D, Buhler S, Teixeira J, Llamas B, et al. Binding affinities of $438 \mathrm{HLA}$ proteins to complete proteomes of seven pandemic viruses and distributions of strongest and weakest HLA peptide binders in populations worldwide. HLA. 2020;96(3):277-298. Epub 2020 Jun 11. https://doi.org/10.1111/tan.13956.
49. Nguyen A, David JK, Maden SK, Wood MA, Weeder BR, Nellore A, et al. Human leukocyte antigen susceptibility map for severe acute respiratory syndrome coronavirus 2. J Virol. 2020;94(13):e00510-e520. https://doi.org/ 10.1128/JVI.00510-20.

50. Sanchez-Mazas A. HLA studies in the context of coronavirus outbreaks. Swiss Med Wkly. 2020;16(150): w20248. https://doi.org/10.4414/smw. 2020.20248.

51. Novelli A, Andreani M, Biancolella M, Liberatoscioli L, Passarelli C, Colona VL, et al. HLA allele frequencies and susceptibility to COVID-19 in a group of 99 Italian patients. HLA. 2020;96(5):610-614. Epub 2020 Sep 3. https:// doi.org/10.1111/tan.14047.

52. Alghamdi J, Alaamery M, Barhoumi T, Rashid M, Alajmi H, Aljasser N, et al. Interferon-induced transmembrane protein-3 genetic variant rs 12252 is associated with COVID-19 mortality. Genomics. 2021;113(4):1733-1741. Epub 2021 Apr 7. https://doi.org/10.1016/j.ygeno.2021.04.002.

53. Kim YC, Jeong BH. Strong correlation between the case fatality rate of COVID-19 and the rs6598045 single nucleotide polymorphism (SNP) of the interferon-induced transmembrane protein 3 (IFITM3) gene at the population-level. Genes (Basel). 2020;12(1):42. https://doi.org/10.3390/ genes 12010042.

54. Fricke-Galindo I, Falfán-Valencia R. Genetics insight for COVID-19 susceptibility and severity: a review. Front Immunol. 2021;1(12): 622176. https:// doi.org/10.3389/fimmu.2021.622176.

55. Lin M, Tseng HK, Trejaut JA, Lee HL, Loo JH, Chu CC, et al. Association of HLA class I with severe acute respiratory syndrome coronavirus infection. BMC Med Genet. 2003;12(4):9. https://doi.org/10.1186/1471-2350-4-9.

56. Khor SS, Omae Y, Nishida N, Sugiyama M, Kinoshita N, Suzuki T, et al. HLA$A^{*}$ 11:01:01:01, HLA-C*12:02:02:01-HLA-B*52:01:02:02, age and sex are associated with severity of Japanese COVID-19 with respiratory failure. Front Immunol. 2021;22(12): 658570. https://doi.org/10.3389/fimmu. 2021.658570

57. Bonaccorsi I, Carrega P, Venanzi Rullo E, Ducatelli R, Falco M, Freni J, et al. HLA-C*17 in COVID-19 patients: Hints for associations with severe clinical outcome and cardiovascular risk. Immunol Lett. 2021;234:44-46. Epub 2021 Apr 24. https://doi.org/10.1016/j.imlet.2021.04.007.

58. Vietzen H, Zoufaly A, Traugott M, Aberle J, Aberle SW, Puchhammer-Stöckl E. Deletion of the NKG2C receptor encoding KLRC2 gene and HLA-E variants are risk factors for severe COVID-19. Genet Med. 2021;23(5):963-967. Epub 2021 Jan 26. https://doi.org/10.1038/s41436-020-01077-7.

59. Shkurnikov M, Nersisyan S, Jankevic T, Galatenko A, Gordeev I, Vechorko $V$, et al. Association of HLA class I genotypes with severity of coronavirus disease-19. Front Immunol. 2021;23(12): 641900. https://doi.org/10.3389/ fimmu.2021.641900.

60. Hu J, Li C, Wang S, Li T, Zhang H. Genetic variants are identified to increase risk of COVID-19 related mortality from UK Biobank data. Hum Genom. 2021;15(1):10. https://doi.org/10.1186/s40246-021-00306-7.

61. Russo R, Andolfo I, Lasorsa VA, Cantalupo S, Marra R, Frisso G, et al. The TNFRSF13C H159Y variant is associated with severe COVID-19: a retrospective study of 500 patients from Southern Italy. Genes (Basel). 2021;12(6):881. https://doi.org/10.3390/genes12060881.

62. SeyedAlinaghi S, Mehrtak M, MohseniPour M, Mirzapour P, Barzegary A, Habibi P, et al. Genetic susceptibility of COVID-19: a systematic review of current evidence. Eur J Med Res. 2021 May 20;26(1):46. https://doi.org/10. 1186/s40001-021-00516-8.

63. Dite GS, Murphy NM, Allman R. Development and validation of a clinical and genetic model for predicting risk of severe COVID-19. Epidemiol Infect. 2021;2(149): e162. https://doi.org/10.1017/S095026882100145X.

64. Zanella I, Zacchi E, Piva S, Filosto M, Beligni G, Alaverdian D, et al. C9orf72 intermediate repeats confer genetic risk for severe COVID-19 pneumonia independently of age. Int J Mol Sci. 2021;22(13):6991. https://doi.org/10. 3390/ijms22136991.

65. Kuo CL, Pilling LC, Atkins JL, Masoli JAH, Delgado J, Kuchel GA, et al. APOE e4 genotype predicts severe COVID-19 in the UK biobank community cohort. J Gerontol A Biol Sci Med Sci. 2020;75(11):2231-2. https://doi.org/ 10.1093/gerona/glaa131.

66. Pathak GA, Singh K, Miller-Fleming TW, Wendt FR, Ehsan N, Hou K, et al. Integrative genomic analyses identify susceptibility genes underlying COVID-19 hospitalization. Nat Commun. 2021;12(1):4569. https://doi.org/ 10.1038/s41467-021-24824-z. 
67. COVID-19 Host Genetics Initiative. Mapping the human genetic architecture of COVID-19. Nature. 2021. Epub ahead of print. https://doi.org/10. 1038/s41586-021-03767-x.

68. Schuler BA, Habermann AC, Plosa EJ, Taylor CJ, Jetter C, Negretti NM, et al. Age-determined expression of priming protease TMPRSS2 and localization of SARS-CoV-2 in lung epithelium. J Clin Investig. 2021;131(1): e140766. https://doi.org/10.1172/JCl140766.

69. Levin AT, Hanage WP, Owusu-Boaitey N, Cochran KB, Walsh SP, Meyerowitz-Katz G. Assessing the age specificity of infection fatality rates for COVID-19: systematic review, meta-analysis, and public policy implications. Eur J Epidemiol. 2020;35(12):1123-1138. Epub 2020 Dec 8. https:// doi.org/10.1007/s10654-020-00698-1.

70. Verma S, Abbas M, Verma S, Khan FH, Raza ST, Siddiqi Z, et al. Impact of I/D polymorphism of angiotensin-converting enzyme 1 (ACE1) gene on the severity of COVID-19 patients. Infect Genet Evol. 2021;91:104801. Epub 2021 Mar 4. https://doi.org/10.1016/j.meegid.2021.104801.

71. Blume C, Jackson CL, Spalluto CM, Legebeke J, Nazlamova L, Conforti F, et al. A novel ACE2 isoform is expressed in human respiratory epithelia and is upregulated in response to interferons and RNA respiratory virus infection. Nat Genet. 2021;53(2):205-214. Epub 2021 Jan 11. https://doi.org/ 10.1038/s41588-020-00759-x.

72. Latini A, Agolini E, Novelli A, Borgiani P, Giannini R, Gravina P, et al. COVID19 and genetic variants of protein involved in the SARS-CoV-2 entry into the host cells. Genes (Basel). 2020;11(9):1010. https://doi.org/10.3390/ genes 11091010.

73. Andolfo I, Russo R, Lasorsa VA, Cantalupo S, Rosato BE, Bonfiglio F, et al. Common variants at 21 q22.3 locus influence MX1 and TMPRSS2 gene expression and susceptibility to severe COVID-19. iscience. 2021;24(4):102322. Epub 2021 Mar 17. https://doi.org/10.1016/j.isci.2021. 102322.

74. Hou Y, Zhao J, Martin W, Kallianpur A, Chung MK, Jehi L, et al. New insights into genetic susceptibility of COVID-19: an ACE2 and TMPRSS2 polymorphism analysis. BMC Med. 2020;18(1):216. https://doi.org/10. 1186/s12916-020-01673-z.

75. Wang F, Huang S, Gao R, Zhou Y, Lai C, Li Z, et al. Initial whole-genome sequencing and analysis of the host genetic contribution to COVID-19 severity and susceptibility. Cell Discov. 2020;6(1):83. https://doi.org/10. 1038/s41421-020-00231-4.

76. Novelli A, Biancolella M, Borgiani P, Cocciadiferro D, Colona VL, D'Apice $\mathrm{MR}$, et al. Analysis of ACE2 genetic variants in 131 Italian SARS-CoV2-positive patients. Hum Genom. 2020;14(1):29. https://doi.org/10.1186/ s40246-020-00279-z.

77. Cuesta-Llavona E, Gómez J, Albaiceta GM, Amado-Rodríguez L, GarcíaClemente M, Gutiérrez-Rodríguez J, et al. Variant-genetic and transcriptexpression analysis showed a role for the chemokine-receptor CCR5 in COVID-19 severity. Int Immunopharmacol. 2021;98:107825. Epub ahead of print. https://doi.org/10.1016/j.intimp.2021.107825.

78. Starčević Čizmarević N, Tota M, Ristić S. Does the CCR5- $\triangle 32$ mutation explain the variable coronavirus-2019 pandemic statistics in Europe? Croat Med J. 2020;61 (6):525-6. https://doi.org/10.3325/cmj.2020.61.525.

79. Bernas SN, Baldauf H, Wendler S, Heidenreich F, Lange V, Hofmann JA, et al. CCR5 $\triangle 32$ mutations do not determine COVID-19 disease course. Int J Infect Dis. 2021;105:653-655. Epub 2021 Mar 2. https://doi.org/10. 1016/j.jijid.2021.02.108.

80. Hubacek JA, Dusek L, Majek O, Adamek V, Cervinkova T, Dlouha D, et al. CCR5Delta32 deletion as a protective factor in Czech first-wave COVID-19 subjects. Physiol Res. 2021;70(1):111-115. https://doi.org/10.33549/physi olres.934647.

81. Habas K, Nganwuchu C, Shahzad F, Gopalan R, Haque M, Rahman S, et al. Resolution of coronavirus disease 2019 (COVID-19). Expert Rev Anti Infect Ther. 2020;18(12):1201-1211. Epub 2020 Aug 4. https://doi.org/10.1080/ 14787210.2020 .1797487$.

82. Russick J, Foy PE, Josseaume N, Meylan M, Hamouda NB, Kirilovsky A, et al. Immune signature linked to COVID-19 severity: a SARS-score for personalized medicine. Front Immunol. 2021;12(12): 701273. https://doi.org/10. 3389/fimmu.2021.701273.

83. Weinreich DM, Sivapalasingam S, Norton T, Ali S, Gao H, Bhore R, et al. REGN-COV2, a Neutralizing Antibody Cocktail, in Outpatients with Covid19. N Engl J Med. 2021;384(3):238-251. Epub 2020 Dec 17. https://doi. org/10.1056/NEJMoa2035002.

84. Novelli G, Liu J, Biancolella M, Alonzi T, Novelli A, Patten JJ, et al. Inhibition of HECT E3 ligases as potential therapy for COVID-19. Cell Death Dis. 2021;12(4):310. https://doi.org/10.1038/s41419-021-03513-1.

85. Majumder J, Minko T. Recent developments on therapeutic and diagnostic approaches for COVID-19. AAPS J. 2021;23(1):14. https://doi.org/10. 1208/s12248-020-00532-2.

86. Salian VS, Wright JA, Vedell PT, Nair S, Li C, Kandimalla M, et al. COVID-19 Transmission, current treatment, and future therapeutic strategies. Mol Pharm. 2021;18(3):754-771. Epub 2021 Jan 19. https://doi.org/10.1021/ acs.molpharmaceut.0c00608.

87. Toor SM, Saleh R, Sasidharan Nair V, Taha RZ, Elkord E. T-cell responses and therapies against SARS-CoV-2 infection. Immunology. 2021;162(1):30-43. Epub 2020 Oct 27. https://doi.org/10.1111/imm.13262.

88. Miersch S, Li Z, Saberianfar R, Ustav M, Brett Case L, Blazer L, et al. Tetravalent SARS-CoV-2 neutralizing antibodies show enhanced potency and resistance to escape mutation. J Mol Biol. 2021;27: 167177. https://doi. org/10.1016/j.jmb.2021.167177.

89. Blanchard EL, Vanover D, Bawage SS, Tiwari PM, Rotolo L, Beyersdorf J, et al. Treatment of influenza and SARS-CoV-2 infections via mRNAencoded Cas13a in rodents. Nat Biotechnol. 2021;39(6):717-26. https:// doi.org/10.1038/s41587-021-00822-w.

90. Nguyen TM, Zhang Y, Pandolfi PP. Virus against virus: a potential treatment for 2019-nCov (SARS-CoV-2) and other RNA viruses. Cell Res. 2020;30(3):189-190. https://doi.org/10.1038/s41422-020-0290-0.

91. Mehrian-Shai R, Novelli G, Vasiliou V, Watt J, Reichardt JKV. Genomics of COVID-19: molecular mechanisms going from susceptibility to severity of the disease. Hum Genom. 2020;14(1):22. https://doi.org/10.1186/ s40246-020-00273-5.

92. Godri Pollitt KJ, Peccia J, Ko Al, Kaminski N, Dela Cruz CS, Nebert DW, et al. COVID-19 vulnerability: the potential impact of genetic susceptibility and airborne transmission. Hum Genom. 2020;14(1):17. https://doi.org/10. 1186/s40246-020-00267-3.

93. Sawyer A, Free T, Martin J. Metagenomics: preventing future pandemics. Biotechniques. 2021;70(1):1-4. https://doi.org/10.2144/btn-2020-0166.

\section{Publisher's Note}

Springer Nature remains neutral with regard to jurisdictional claims in published maps and institutional affiliations.

Ready to submit your research? Choose BMC and benefit from:

- fast, convenient online submission

- thorough peer review by experienced researchers in your field

- rapid publication on acceptance

- support for research data, including large and complex data types

- gold Open Access which fosters wider collaboration and increased citations

- maximum visibility for your research: over 100M website views per year

At BMC, research is always in progress.

Learn more biomedcentral.com/submissions 